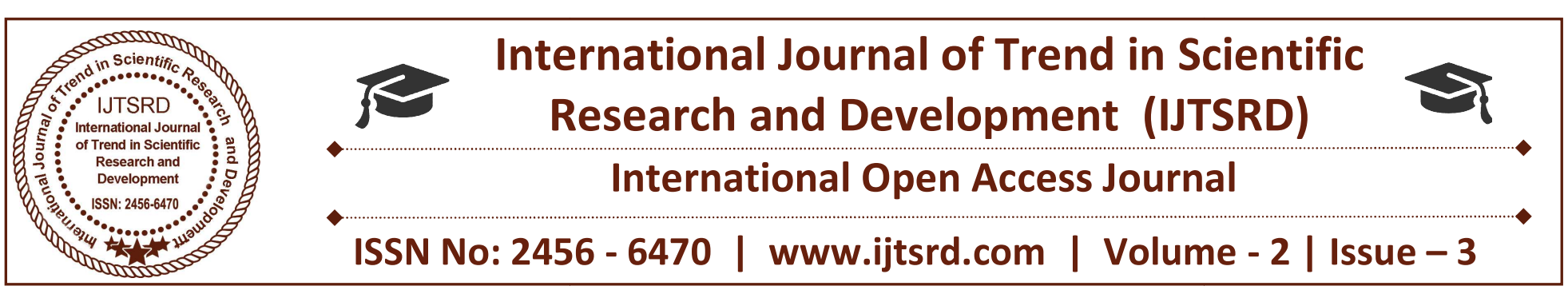

\title{
A Study on Evaluation \& Effectiveness of Training and Development of Employees in Tirupur Garment Indusrty
}

T. Sreerekha

Assistant Professor, Management, NIFT - Tea College of Knitwear Fashion, Tirupur, Tamil Nadu, India

\author{
H. Labiba \\ III BBA, NIFT - Tea College of Knitwear Fashion, \\ Tirupur, Tamil Nadu, India
}

\begin{abstract}
In this competitive world, training plays an important role in the competent and challenging format of business. Training is the nerve that suffices the need of fluent and smooth functioning of work which helps in enhancing the quality of work life of employees and organizational development too. Development is a process that leads to qualitative as well as quantitative advancements in the organization, especially at the managerial level; it is less considered with physical skills and is more concerned with knowledge, values, attitudes and behaviour in addition to specific skills. Hence, development can be said as a continuous process whereas training has specific areas and objectives. So, every organization needs to study the role, importance and advantages of training and its positive impact on development for the growth of the organization. Thus, employee training and development programs are important aspects which are needed to be studied and focused on. This paper focuses and analyses the literature findings on importance of training and development of employees.
\end{abstract}

Keywords: Human Resource Management, Training, Development

\section{INTRODUCTION}

In all organisations, like manpower planning and staffing, training is also the function of the personnel manager. In recent years, however, there has been a growing dissatisfaction with the functioning of personnel department because in many cases they have failed to achieve the twin goals of increased productivity and employee satisfaction. As a result a new concept of dealing with the human resource known as Human Resource Development (HRD) has come into being. This concept differs from personnel management at least in three ways. One, whereas the personnel management merely reacts to the organisation's training needs as and when they arise, HRD emphasises the need for every organisation to continuously develop its employees competencies in a planned way. Two, whereas personnel management relates all its functions (such as recruitment, training, performance appraisal, etc.) to employees positions, HRD relates them to employees roles. The principal tasks of a human resource development manager are to understand these roles, match the role and the person and develop persons in their roles. Three, whereas personnel management does not give much weight age to the procedural aspect of a training technique, HRD considers this aspect as crucial for achieving lasting development of human competencies.

Training is different from education. Training is the act of increasing the knowledge and skill of an employee for doing a particular job. It is concerned with imparting specific skills for particular purposes. On the other hand, education is a broader term concerned with increasing the general knowledge and understanding of the employee's total environment. Thus, when we teach a person how to assemble two objects and tighten a nut, we are training him to do a specific job but when we are giving him a course in engineering, it is education. The distinction between the two is like the distinction between applied and pure sciences. 
Training is also different from development. Being always work - oriented, training carries the narrow implication of imparting to an individual some specific skills only. In contrast, development emphasises an unfolding process and carries an implication of an individual's growth and maturisation.

Training is not something that is given only once to new employees. All employees- new and oldlearn and receive training throughout their stay in the organisation. This is so because in the process of directing employees' efforts an administering rewards and punishment to them, the manager continually shapes their behaviour everyday whether consciously or unconsciously.

\section{EVALUTION \& EFFECTIVENES TRAINING AND DEVELOPMENT}

Evaluation is the structured interpretation and giving of meaning to predicted or actual impact of proposals or result. It can be also be summative, drawing lessons from a completed action or project or on organisation at a later point in time or circumstance. Evaluation is inherently a theoretically informed approach and consequently any particular definition of evaluation would have been tailored to its context the theory needs, purpose, and methodology of the evaluation process itself.

Something that is effective work well and produces the results that were intended. Effective means particular role or result in practice, though not officially or in theory. When something such as law or an agreement become effective, it begins officially to apply or be valid

Human resources are the most valuable assets of any organization. With the machines, materials and even the money, nothing gets done without manpower. The effective function of any organization requires that employees learn to perform their jobs at a satisfactory level of proficiency. Here is the role of training. Employee training tries to improve skill or add to the existing level of the knowledge so that the employee is better equipped to do his present job or to prepare him for higher position with increased responsibilities. However individual growth is not an end itself. Organization viability, that it should adapt itself to a changing environment. Employee growth and development has to be seen in the context of this change.

\section{SCOPE OF THE STUDY}

The scope of the study covers in depth, the various training practices, modules, formats being followed in Tirupur garment industry. The different training programmes facilitated in the garment companies by the faculties, outside agencies or professional groups. It also judges the enhancement of the knowledge \& skill of employees and feedback on its effectiveness.

\section{OBJECTIVES OF THE STUDY}

The specific objectives of the study are:

To find the demographic profile of the garment employees.

To find the effectiveness of the training program conducted.

To measure the development and skill improvement due to training.

To find the training methods and evaluation of the training programmes

\section{RESEARCH METHODOLOGY}

The research design used for the study is a descriptive research design. The main characteristic of this method is that the researcher has no control over the variables. It is only record of the feeling of training and development employees towards their work life. In this study non-probability sampling procedure is used, under this convenience sampling method is adopted. The total sample size constitutes of 100 employees in Cotton in Tirupur garment City.

\begin{tabular}{|l|l|}
\hline \multicolumn{1}{|c|}{ Data source } & \multicolumn{1}{c|}{ Primary data } \\
\hline Research Approach & Survey \\
\hline Research Instrument & $\begin{array}{l}\text { Interview Schedule cum } \\
\text { Questionnaire }\end{array}$ \\
\hline Research of Conduct & Personal \\
\hline
\end{tabular}

\section{Tools for analysis:}

The primary and secondary data were presented in the form of table and these tables were systematically 
analysed with the aid of some statistical techniques like percentage, weighted average and Henry Garrett Ranking Technique.

\section{LIMITATION OF STUDY}

- Some of the respondents are willing to answer the questions

- Some of the respondents were afraid to given true information in some cases.

- There may be bias on the part of employee while answering to the question.

- The validity of the study may change according to the prevailing situation.

\section{REVIEW OF LITERATURE}

According to Shelley Frost, Demand Media Training:

Is a crucial component in preparing new employees for their positions and keeping existing employees current on critical information. To be effective, a training program needs a specific purpose with appropriate training methods. Understanding the factors that influence training programs enables you to develop or change your current employee education to make it fit the needs of your business and your employees.

\section{According to Henry Ongori (2011):}

Jennifer Chishamiso Nzonzo, training and development has become an issue of strategic importance. Although many scholars have conducted research on training and development practices in organizations in both developing and developed economies, it is worth mentioning that most of the research has concentrated on the benefits of training in general. There is however, limited focus on evaluation of training and development practices in organizations.

\section{According to Haslinda ABDULLAH (2009):}

The challenges faced by employers and organizations in the effective management of HR T\&D varied from concerns about the lack of intellectual HR professionals to coping with the demand for knowledge-workers and fostering learning and development in the workplace. The core and focal challenge is the lack of intellectual HRD professionals in manufacturing firms, and this suggests that employers viewed HR T\&D as a function secondary to HRM and perhaps considered it as being of lesser importance. This implication could lead to the ineffective implementation of HR T\&D activities and increase ambiguity and failure in effectively managing HR T\&D as a whole.

\section{According to Ananth (1998):}

He pointed out different problems faced by the organization in handling the corporate finance such as the time of procurement and investment of funds. He suggested that the organisation must relate itself with the needs of changing environment by taking good decisions through professionally trained people.

\section{According To Fizzah(2011):}

The purpose of the research is to find out how training and development effect organizational performance and to find out what in the impact of training and development in organization Data is collected from the 100 members of different organizations. And the previous researches carried out on training and development. Training and development is important for the employees in organization, it helps the employees to improve their skills and to give good performance in workplace. There is a big relation between training and development with the organization performance and the relationship is discussed in the paper.

\section{According to Iftikhar Ahmad and Sirajud Din (2009):}

Training and development is adopted by organizations to fill the skill gap of employees. Training evaluation must be appropriate for the person and situation. Evaluation will not ensure effective learning unless training is properly designed. Successful evaluation depends upon whether the means of evaluation were built into the design of the training program before it was implemented.

\section{According to Bates and Davis (2010):}

Usefulness of training programme is possible only when the trainee is able to practice the theoretical aspects learned in training programme in actual work environment. They highlighted the use of role playing ,cases, simulation, mediated exercises, and computer based learning to provide exposure to a current and relevant body of knowledge and real world situations 


\section{Cheng and Ho (2001):}

Discuss the importance of training and its impact on job performance: While employee performance is one of the crucial measures emphasized by the top management, employees are more concerned about their own productivity and are increasingly aware of the accelerated obsolescence of knowledge and skills in their turbulent environment. As the literature suggests, by effectively training and developing employees, they will become more aligned for career growth - career potential enhances personal motivation implemented.

\section{DATA ANALYSIS AND FINDINGS}

Table 1: Demographic factors

\begin{tabular}{|c|c|c|c|}
\hline $\begin{array}{l}\text { S. } \\
\text { No }\end{array}$ & VARIABLES & CLASSES & PERCENTAGE \\
\hline \multirow[b]{2}{*}{1.} & \multirow[t]{2}{*}{ GENDER } & Male & 40 \\
\hline & & Female & 60 \\
\hline \multirow{3}{*}{2.} & & $20-25$ & 40 \\
\hline & & $\mathrm{C}-25-30$ & 30 \\
\hline & & $30-35-10$ & 25 \\
\hline \multirow{4}{*}{3.} & \multirow{4}{*}{ Year Of Experience } & $\begin{array}{l}\text { Above } 40 \\
\text { Less than } 3 \text { years }\end{array}$ & Q \\
\hline & & 3 to 5 years & 40 \\
\hline & & Less than 5 years & 8 \\
\hline & & More than 7 years & 103 \\
\hline \multirow{2}{*}{4.} & \multirow{2}{*}{ Marital Status } & thicitin Married & all \\
\hline & & Trendu married notil & 60 \\
\hline \multirow{4}{*}{5.} & \multirow{4}{*}{ Education Qualification } & $\mathrm{PG}$ & 00 \\
\hline & & Resea UG allo & 10 \\
\hline & & HSC\& Diploma & 40 \\
\hline & & SSLC & 0 \\
\hline \multirow{3}{*}{6.} & \multirow{3}{*}{$\begin{array}{l}\text { Training programs } \\
\text { attended }\end{array}$} & $1-2$ & 10 \\
\hline & & $001 \mathrm{~L}: 2-3=04 / 0$ & 20 \\
\hline & & $\frac{3-4}{4-5}$ & $\begin{array}{r}-10 \\
60\end{array}$ \\
\hline
\end{tabular}

Source: Primary data

\section{Interpretation:}

The above table shows that the majority 60 percent of the people are female, 40 percent of the respondents were in the age group of $20-25,50$ percent of the respondents had year of experience is less than 3 years, 60 percent of the respondents are unmarried, 50 percent of the respondents are SSLC, 60 percent of the respondents are 4-5 training programs attended.
Table 2: Weighted average of perception towards effectiveness of training given to the employee's in Tirupur city

\begin{tabular}{|l|c|}
\hline \multicolumn{1}{|c|}{ FACTORS } & TOTAL SCORE \\
\hline Planning & 3.85 \\
\hline $\begin{array}{l}\text { Helpful in the work } \\
\text { environment }\end{array}$ & 4.1 \\
\hline Helpful in personal growth & 4.25 \\
\hline Improving self-confident & 4 \\
\hline Role playing & 3.8 \\
\hline Computer based training & 2.8 \\
\hline $\begin{array}{l}\text { Enhance employee } \\
\text { capacity }\end{array}$ & 4.3 \\
\hline $\begin{array}{l}\text { Enrich } \\
\text { efficiency }\end{array}$ & 4.1 \\
\hline Total employee & $\mathbf{3 1 . 2}$ \\
\hline
\end{tabular}


Source: Primary data

Mean score $=3.9$

The details of effectiveness of training given to the employee's are presents in the above table mean score value is 3.9 .

From the above table it can be inferred that the mean score is 3.9. Factors such as Helpful in the work environment, Helpful in personal growth, Improving self- confident, Enhance employee capacity, Enrich employee efficiency measures are score above 3.9 Such as $4.1,4.25,4,4.3$, and 4.1 respectively. Hence the respondents found these attributes to be highly satisfactory.

The factors such as Planning, Role playing, Computer based training are below 3.9 such as 3.85, 3.8 and 2.8 respectively therefore these factors are dissatisfied by the respondents.

Table 3: Weighted average of perception towards On -the- job Off -the-job Methods given to the employee's in Tirupur city

\begin{tabular}{|l|c|}
\hline FACTORS & TOTAL SCORE \\
\hline A. On-the-job methods & \\
\hline Orientation training & 5.3 \\
\hline Job instruction training & 3.9 \\
\hline Apprentice training & 4 \\
\hline Job rotation & 2.35 \\
\hline Coaching & 3.35 \\
\hline B. Off-the-job methods & 3.6 \\
\hline Vestibule & 3.45 \\
\hline Lecture & 3.05 \\
\hline Special study & 3.75 \\
\hline Conference or Discussion & 3.3 \\
\hline Simulation & 3.05 \\
\hline Laboratory training & \\
\hline Case study & \\
\hline Total &
\end{tabular}

Source: Primary data

Mean score $=3.32$

The details of On-the-job Off-the-job methods given to the employee's are presented in the above table the mean score value is 3.32

From the above table in can be inferred that the mean score is 3.32. Factors such as Coaching, Vestibule, Special study, Simulation, Orientation training, Job instruction training, Apprentice training, Lecture measures are score above 3.32 Such as $5.3,3.9,4,3.35,3.35,3.6,3.45$, and 3.75 respectively. Hence the respondents found these attributes to be highly satisfactory.

The factors such as Job rotation, Conference or Discussion, Laboratory training, Case study are below 3.32 such as $2.8,3.05,3.3$, and 3.05 respectively therefore these factors are dissatisfied by the respondents.

Table 4: Evaluation of the training by the employee's

\begin{tabular}{|c|c|l|l|l|}
\hline S.No & $\begin{array}{l}\text { Evaluation rank by the } \\
\text { employee's }\end{array}$ & $\begin{array}{l}\text { TOTAL } \\
\text { GARRETT } \\
\text { SCORE }\end{array}$ & Mean score & RANK \\
\hline 1. & Result & 4380 & 43.80 & II \\
\hline 2. & Behaviour & 3800 & 38.00 & IV \\
\hline 3. & Learning & 4400 & 44.00 & I \\
\hline 4. & Reaction & 4050 & 40.50 & III \\
\hline
\end{tabular}

Source: Primary data 
Interpretation:

Most of the employees are having evaluation of the training with Learning which I rank, Result are II rank, Reaction III rank, Behaviour is IV rank.

\section{SUGGESTIONS}

- Training and development should be routine in the company environment. Regular training program will help the employee's to improve the technical skills and in turn increase the job satisfaction.

- It is recommended that the trainer who gives training should be will qualified in order to given better training to employee.

- Majority of the respondents hinted that all employees need the opportunity in order to work more efficiency

- Majority of the respondents hinted that working environment is also an important factor that favouring training.

- It is recommended that, creating good physical working environment can indirectly influences his or her feelings on the job.

- Giving award and rewards to the workers for their best performance can do motivation.

- Death or injury of any employee's during the tenure of employment should be paid with a compensation amount to workers' family by the employer.

- Majority of the respondents have hinted that selfreliance and motivation during is also a major factor that favours increase in efficiency.

\section{CONCLUSION}

Training and development programs play a vital role in every organization. These programs improve Employee Performance at workplace, it updates Employee Knowledge and enhances their personal Skills and it helps in avoiding Managerial Obsolescence. With the use of these programs, it is easier for the management to evaluate the job performance and accordingly take decisions like employee Promotion, rewards, compensations, welfare facilities, etc. These training programs also help the managers in succession planning, employee retention and motivation. It creates Efficient and
Effective employees in the Organization. The need for training \& development is determined by the employee's performance deficiency, computed as follows: Training \& Development need Standard performance - Actual performance .Training enhances the overall performance of an organization in various ways. The major areas where employees are normally trained in an organization are Soft- skill Development, Personality Development, Interpersonal Relationship, Problem solving techniques, Managerial and Supervisory Training Program, quality improvement programs, technical processes, quality circle programs, Time management skills, employee efficiency development programs, violence prevention programs, regulatory compliances, goal setting and implementation of programs, workplace safety management, workplace communication, and so on. Training enables the employees to develop their skills within the organization and hence naturally helps to increase the organization's market value, earning power of the employees and job security of the employees. Training moulds the employee's attitude and helps them to achieve a better cooperation within the organization. Training and Development programs improve the quality of work-life by creating an employee supportive workplace.

This project study would be of highly useful to the management based on the findings of the survey and it has provided valuable suggestion to the management. It can be concluded that the study believes if the training and development and HR department in the organization consider the suggestion and implement in the future the training programs offered it will be effective and will serve the need of the employees by increasing their efficiency.

\section{REFERENCES}

1. Abdul Hameed Aamer Waheed (2011): -Employee Development and Its Affect on Employee Performance A Conceptual Framework\|. International Journal of Business and Social Science Vol. 2 No. 13 [Special Issue - July 2011] 224.

2. Atif et al.(2010): - Employee Retention Relationship to Training and Development: A Compensation Perspectivell. African Journal Of Business Management. Vol. 5(7), pp. 2679-2685.

3. Colombo, Emilio \& Stanca, Luca. (2008): -The Impact of Training on Productivity: Evidence from a Large Panel of Firms, Available at SSRN. 
4. Ekaterini Galanou, Constantinos-Vasilios Priporas (2009): - A model for evaluating the effectiveness of middle managerse ${ }^{e c}$ training courses: evidence from a major banking organization in Greecell. International Journal of Training and Development, pp 221-245.

5. Jelena Vemic(2007): -Employee Training And Development And The Learning Organizationll. Facta Universitatis Series; Economics and Organization Vol. 4, No 2, 2007, Pp. 209 - 216.

6. Kate Hutchings, Cherrie J. Zhu, Brain K, Cooper, Yiming Zhang and Sijun Shao (2009): -Perceptions of the effectiveness of training and development of ,grey-collare workers in the People's Republic of Chinall. Human Resource Development International, Vol.12, No.3, pp 279296.

7. Rama V. Devi \& Nagurvali Shaik (2012): -Training \& Development - A Jump Starter For
Employee Performance And Organizational Effectivenessll. International Journal Of Social Science \& Interdisciplinary Research Vol.1 Issue 7, July 2012, Issn 22773630.

8. Rohan, S. \& Madhumita, M. (2012): - Impact of Training Practices on Employee Productivity: A Comparative Studyll. Interscience Management Review (IMR) ISSN: 2231-1513 Volume-2, Issue$2,2012$.

\section{Books:}

1. Human Resource Management-Rao V.S.P.Excel Books, 2010

2. Humanresource Management- Lawrence S.Kleeman

3. Human Resource Management: A South Asian Perspective, Snell, Bohlander, \& Vohra, Ceneage Learning, 16th Rep.2012

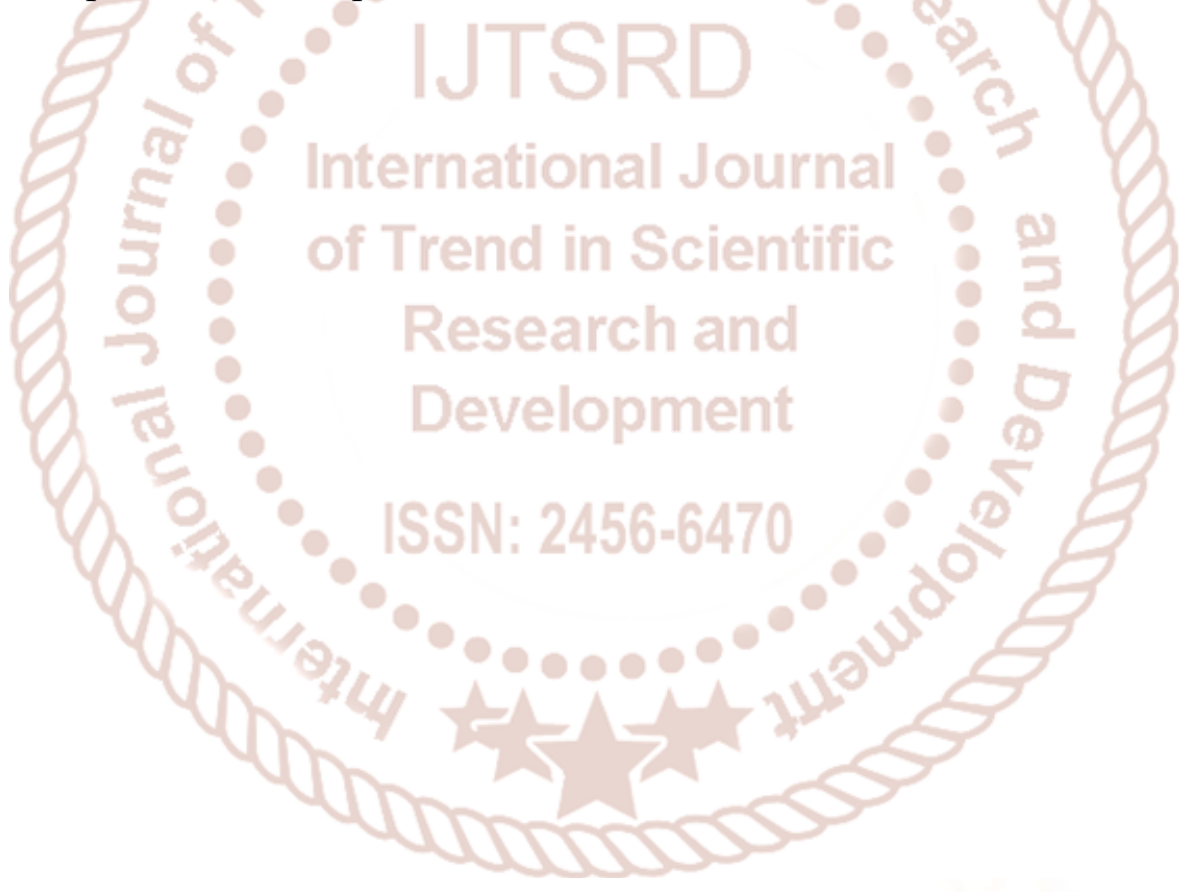

